\title{
Epidemiological Study on Breast Cancer Associated Risk Factors and Screening Practices among Women in the Holy City of Varanasi, Uttar Pradesh, India
}

\author{
Shatabdi Paul ${ }^{1}$, Prem Prakash Solanki ${ }^{1 *}$, Uday Pratap Shahi², Saripella \\ Srikrishna ${ }^{3}$
}

\begin{abstract}
Background: Breast cancer is the second most cause of death ( 1.38 million, $10.9 \%$ of all cancer) worldwide after lung cancer. In present study, we assess the knowledge, level of awareness of risk factors and screening practices especially breast self examination (BSE) among women, considering the non-feasibility of diagnostic tools such as mammography for breast screening techniques of breast cancer in the holy city Varanasi, Uttar Pradesh, India. Materials and Methods: A cross-sectional population based survey was conducted. The investigation tool adopted was self administrated questionnaire format. Data were analysed using SPSS 20 version and Chi square test to determine significant association between various education groups with awareness and knowledge, analysis of variance was applied in order to establish significance. Results: The attitude of participants in this study, among 560 women 500 (89\%) responded (age group 18-65 years), 53.8\% were married. The knowledge about BSE was very low $(16 \%)$ and out of them $15.6 \%$ were practised BSE only once in life time. study shown that prominent age at which women achieve their parity was 20 yrs, among 500 participants 224 women have achieved their parity from age 18 to 30 yrs. Very well known awareness about risk factors of breast cancer were alcohol $(64.6 \%)$, smoking $(64 \%)$ and least known awareness risk factors were early menarche $(17.2 \%)$ and use of red meat $(23 \%)$. The recovery factors of breast cancer cases were doctors support $(95 \%)$ and family support $(\mathbf{9 4 . 5 \% )}$ ) as most familiar responses of the holy city Varanasi. Conclusions: The study revealed that the awareness about risk factors and practised of BSE among women in Varanasi is extremely low in comparison with other cities and countries as well (Delhi, Mumbai, Himachal Pradesh, Turkey and Nigeria). However, doctors and health workers may promote the early diagnosis of breast cancer.
\end{abstract}

Keywords: Awareness - breast cancer - breast self examination - knowledge - parity - risk factor - screening practise

Asian Pac J Cancer Prev, 16 (18), 8163-8171

\section{Introduction}

Cancer is a major problem with increasing trend of occurrence worldwide. The number of newly diagnosed cancer cases in 2008 was approximately 12.7 million, with 5.6 million in economically more developed countries and 7.1 million in less developed countries. Breast cancer incidences of new cases in female were 1,383,523 with mortality of 458,367 . In more developed countries, the incidences of breast cancer was 692,242 and number of death was $1,89,488$. In less developed countries, the incidences and mortality of such cases were 691,281 and 268,879 respectively, age standardized incidences and mortality rates for breast cancer was 39 and 12.5 per 100,000 respectively (Thun et al., 2011). The global burden of breast cancer diagnosed was 1.38 million, which occupies second position among all cancers. New cases estimated in developed and developing region population is $1: 4$ in a population of $6,90,000$. The rate of incidence was high that is, greater than 80 per 100,000 in developed regions of the world except Japan and low in most developing regions that is, less than 40 per 100,000. But its rates were varying in Eastern Africa to Western Europe from 19.3 to 89.9 per 100,000 women respectively (Ferlay et al., 2010).

India is a culturally rich and diverse country with a current population of 1.2 billion. Although concerning about public health non-communicable diseases are assuming important in developing countries, where at present cancer is leading cause of death. From the incidences of morbidity and mortality rate of breast cancer showing an increasing trend of risk factors associated with breast cancer (Gupta et al., 2002). Recently rise in incidences of risk factors of breast cancers due to

${ }^{1}$ Department of Chemistry, Faculty of Science, ${ }^{2}$ Department of Radiotheraphy \& Radiation Medicine, Institute of Medical Sciences, ${ }^{3}$ Department of Biochemistry, Faculty of Science, Banaras Hindu University, Varanasi, Uttar Pradesh, India *For correspondence: ppsolanki@bhu.ac.in,ppsolankibhu@gmail.com 
urbanisation, life expectancy, life styles and interaction pattern of people with environment and chemical causes leading to the onset of these non-communicable diseases (Khokhar, 2012).

Risk factors of breast cancer are as gender, age, race, family history and genetic factor, personal health history like early menarche and late menopause, reproductive history, certain genome changes, dense breast tissue, lack of physical activity, poor diet, obesity, lack of awareness, alcoholism, exposure to radiation and nulliparous, poor breast feeding, oral contraceptive and life-style etc (Pherson et al., 2000). In an earlier study, it was found that literacy and employment (i.e. higher education and income) increases the breast cancer risk factor by approximately $25 \%$. A higher income group and staying single with delayed marriage may increase the risk of breast cancer (Harrison et al., 2010). A study has revealed that risk (threshold age) to be susceptible to breast cancer is between the age of 40s \& 50s years in Asian countries a decade earlier but for western country the peak age is in between $60 \& 70$ years (Leong et al., 2010). Other study has shown that unmarried women, nulliparous women had 2 fold higher risk of breast cancer than multi-parous women and also late marriage (above $30 \mathrm{yrs)}$ and late age at first pregnancy above 30 yrs (Rao et al., 1994). Further it has been found that $20.7 \%$ of 226 breast cancer patients had a positive family history (Saxena et al., 2005). Over all, in all types of cancers, $87 \%$ non vegetarians were at higher risk (Ganjewala, 2009). In a multicentre case control study, it was found that duration of breast feeding and breast cancer risk is inversely proportional (Gajalakshmi et al., 2009; Meshram et al., 2009).

In cancer statistics (2000) mortality rate of breast cancer patients were $75 \%$ of United State (Greenlee et al., 2000). Increased incidences of cancer have revealed that cancer patients are diagnosed at later and untreatable stage (Singh et al., 2014). However, majority of patients with breast cancer have a fair chance of survival, if it is detected at an early stage and treated appropriately (Olowokere et al., 2012). Therefore, early detection and effective treatment are very important to reduce morbidity and mortality of breast cancer. BSE and mammography are believed to be effective techniques for ensuring early detection of breast cancer. The programme to encourage BSE was first established in Europe, Australia, \& North America in 1950s (Austoker, 2003). Early diagnosis of breast cancer by BSE is an important in improving the survivals in developing countries where sophisticated diagnostic screening techniques are not easily accessible in terms of affordability and availability. Since, in mammography, women don't want to expose their body due to social constrains. Hence, BSE is a simple, feasible and its procedure available free of cost for early detection in developing countries (Shrivastava et al., 2013). Knowledge and awareness about risk factors and feasible screening practice as BSE is important to make them to reduce the incidences of breast cancer.

\section{Objective}

Breast cancer awareness programmes and screening procedures seems to have inadequate reach from the general female population in Varanasi city as compared to large and metro cities like Delhi, Kolkata, Mumbai, Chennai and Hyderabad etc. Women are mostly not aware about breast cancer and importance of medical program and care due to illiteracy. This leads to develop advanced stage with poor treatment outcome, non-adaptability to screening process along with lower concerns for Indian society may further add to delayed treatment that ultimately results in psychological and financial constraints. The present study was included students, teachers, working women, and housewives of age group 18-65 yrs in and around the Varanasi city. The women represent various culture, traditions and habits to make Varanasi multicultural and multilingual place.

Hence, the aim of our study is to assess knowledge and the awareness about the risk factors, recovery factors and the screening practices for early detection of breast cancer among the women of the holy city Varanasi.

\section{Materials and Methods}

This study used self administrated questionnaire which was prepared on the basis of information collected from literature (Secginli and Nahcivan, 2006; Ahuja and Chakrabarti, 2009; Khokhar, 2009; Alharbi et al., 2012; Olowokere et al., 2012; Fotedar et al., 2013) consisted of six parts as general information, the personal dietary habit, health awareness, breast cancer awareness, risk factors and recovery factors of breast cancer. In the questionnaire format mostly options are Yes / No/ can't say.

Sampling and data collection: Sample subjects were randomly selected from various regions of Varanasi city. Subjects were 4 decade (range 18 to $65 \mathrm{yrs}$ ) of 560 women, out of which 60 women were refused to participate in this study. Questionnaire format was prepared both in English and native Hindi language for better communication and understanding. The data collection was done by investigators themselves.

Statistical analysis: Raw data which obtained from the awareness study were screened and analysed by SPSS-20 statistically software for data processing. The percentage of knowledge and awareness was calculated among 500 women.

The main hypothesis was the level of awareness about the risk factors, with the various education levels and it was also hypothesized that the knowledge of BSE as well as performance of BSE in various education levels of women would be varied. The data were analyzed by description studies chi sq. test and analysis of variance based on the above analysis, in order to find out the appropriate conclusion.

Ethical consideration: All necessary approvals for carrying out the research were obtained. The ethical committee of Faculty of Science, Banaras Hindu University, Varanasi, has approved the research work (No.: F. Sc./Ethical/2013-14 dated: 30 ${ }^{\text {th }}$ April, 2013), in order to maintain confidentiality of the questionnaire response. 
Questionnaires were presented to 560 women, out of which 500 women were agreed to participate and to fill up the questionnaire and discuss on various issues of breast cancer and returned back. Here, general information about participated women and their habit and health is given in detail and knowledge \& awareness about screening practices (BSE and mammography), risk factors and recovery factors of breast cancer are discussed.

General information: Proportion of participated women was included as 18-30 yrs (66\%), 31-50 yrs (24\%) and 51-65 yrs (10\%) in this study. In participated women, minimum and maximum age was 18 and $65 \mathrm{yrs}$ respectively, while maximum proportion of women was fallen in age between 18-30 yrs (66\%) as shown in Table 1 and Figure 1.

Marital status of participated women was as married (53.8\%), unmarried (44\%) and widowed women (2.2\%). Most of the women (86.6\%) in the study were educated as High School (7.2\%), Intermediate (8\%), Undergraduate (45.6\%), Postgraduate (20.4\%), PhD (5.4\%) and $13.4 \%$ were illiterate. Majority of participated women were student $(53.80 \%)$, followed by housewife $(29.6 \%)$ and employ (16.6\%). Religion of participated women was found as Hindu (92.6\%), Muslim (6.6\%), Christian (0.6\%) and other $(0.2 \%)$. Mostly participated women were from urban $(74.6 \%)$ and $25.4 \%$ from rural.

Habit: The life-style characteristics of participated women in the study is shown in Table 2, as stressful life, $28.4 \%$ of women very often had stressful daily life whereas $60.4 \%$ had stress occasionally; however $11.2 \%$

Table 1. General Information about Participated Women

\begin{tabular}{lcc}
\hline General information & $\begin{array}{c}\text { Frequency } \\
(\mathrm{n}=500)\end{array}$ & $\begin{array}{c}\text { Percentage } \\
(\%)\end{array}$ \\
\hline Age groups (yrs) & & \\
18-30 & 330 & 66 \\
$31-50$ & 120 & 24 \\
$51-65$ & 50 & 10 \\
Marital status & & \\
Married & 269 & 53.8 \\
Unmarried & 220 & 44 \\
Widowed & 11 & 2.2 \\
Education level & & \\
Illiterate & 67 & 13.4 \\
High school & 36 & 7.2 \\
Intermediate & 40 & 8 \\
Undergraduate & 228 & 45.6 \\
Postgraduate & 102 & 20.4 \\
PhD & 27 & 5.4 \\
Occupation & & \\
Student & 269 & 53.8 \\
Housewife & 148 & 29.6 \\
Employ & 83 & 16.6 \\
Religion & & \\
Hindu & 463 & 92.6 \\
Muslim & 33 & 6.6 \\
Christian & 3 & 0.6 \\
Others & 1 & 0.2 \\
Habitat & & \\
Rural & 127 & 74.6 \\
Urban & 373 & \\
\hline
\end{tabular}

did not feel any stress in their day to day life. Physical exercise, women were involved in physical exercise quite often in $38.4 \%$ whereas $44 \%$ were occasionally in physical exercise, $17.6 \%$ of women were not habitual with physical exercise. Source of drinking water was used as RO (reverse osmosis) $42.4 \%$, tap water $42.6 \%$, underground water intake $14.4 \%$ and pond water $0.6 \%$. Use of vegetables and fruits was very common $98 \%$ responded with yes and only $2 \%$ were responded not used. Soya food often used was $21.0 \%$, whereas most of women $(65.8 \%)$ were not used and 13.2 women were never used. Women frequently consumed non-vegetarian diet in their daily life were $12.0 \%$, sometimes $(36.6 \%)$ and most of women (51.4\%) were responded not used. Alcohol consumption, women who habitual, was $0.2 \%$, sometimes user were $3.8 \%$, most of women $(95.4 \%$ ) were never taken alcohol and ex-drinker were just $0.6 \%$. Most of the women (97.2\%) in this study were responded that never smoke in their daily life, whereas occasionally smoker were $2 \%$ and ex-smoker were $0.8 \%$. Use of cosmetics, very frequently

Table 2. Information about Habits of Participated Wonen in their Daily Life

\begin{tabular}{|c|c|c|}
\hline Parameter & $\begin{array}{l}\text { Frequency } \\
\quad(\mathrm{n}=500)\end{array}$ & $\begin{array}{c}\text { Percentage } \\
(\%)\end{array}$ \\
\hline \multicolumn{3}{|c|}{ Do you feel stressful life? } \\
\hline Often & 142 & 28.4 \\
\hline Sometimes & 142 & 60.4 \\
\hline Never & 56 & 11.2 \\
\hline \multicolumn{3}{|c|}{ Habitual with physical exercise } \\
\hline Often & 192 & 38.4 \\
\hline Sometimes & 220 & 44 \\
\hline Never & 88 & 17.6 \\
\hline \multicolumn{3}{|l|}{ Drinking water source } \\
\hline RO & 212 & 42.4 \\
\hline Tap water & 213 & 42.6 \\
\hline Soil water or well & 72 & 14.4 \\
\hline Pond water & 3 & 0.6 \\
\hline \multicolumn{3}{|c|}{ Use of vegetables and fruits } \\
\hline Yes & 490 & 98 \\
\hline No & 10 & 2 \\
\hline \multicolumn{3}{|l|}{ Use of soya food } \\
\hline Often & 105 & 21 \\
\hline Sometimes & 329 & 65.8 \\
\hline Never & 66 & 13.2 \\
\hline \multicolumn{3}{|c|}{ Use of non vegetarian food } \\
\hline Often & 60 & 12 \\
\hline Sometimes & 183 & 36.6 \\
\hline Never & 257 & 51.4 \\
\hline \multicolumn{3}{|l|}{ Habitual with alcohol } \\
\hline Often & 1 & 0.2 \\
\hline Sometimes & 19 & 3.8 \\
\hline Never & 477 & 95.4 \\
\hline Ex-drinker & 3 & 0.6 \\
\hline \multicolumn{3}{|l|}{ Habitual with smoke } \\
\hline Often & 0 & 0 \\
\hline Sometimes & 10 & 2 \\
\hline Never & 486 & 97.2 \\
\hline Ex-smoker & 4 & 0.8 \\
\hline \multicolumn{3}{|l|}{ Use of cosmetics } \\
\hline Often & 75 & 15 \\
\hline Sometimes & 309 & 61.8 \\
\hline Never & 116 & 23.2 \\
\hline
\end{tabular}




\section{Shatabdi Paula et al}

by women was $15.0 \%, 61.8 \%$ women were occasionally used cosmetics and the proportion of women never used was $23.2 \%$.

Health: After assessing the menstruation history of participated women, it was found that $93.2 \%$ women having regular but $6.8 \%$ women having irregular menstruation and $15.2 \%$ have attained menopause.

Association between age at first full term pregnancy and breast cancer risk: The strength of the association between age at first birth and breast cancer risk has varied considerably, risk gradually increases in those who has attained parity after 27 yrs, or nulliparous women. A study has reported that nulliparous women have higher risk than parous women because they certainly exposed themselves for breast cancer malignancy due to varied hormonal activity (Jennifer et al., 1993).

In this study, out of 500 women 280 women were married (include widowed) as given in Table 1, in which 235 women $(47 \%)$ were attained parity and 45 women (9\%) did not achieve parity. In 45 women, $20 \%$ women were from age group 28-30yrs and $22 \%$ of women were age

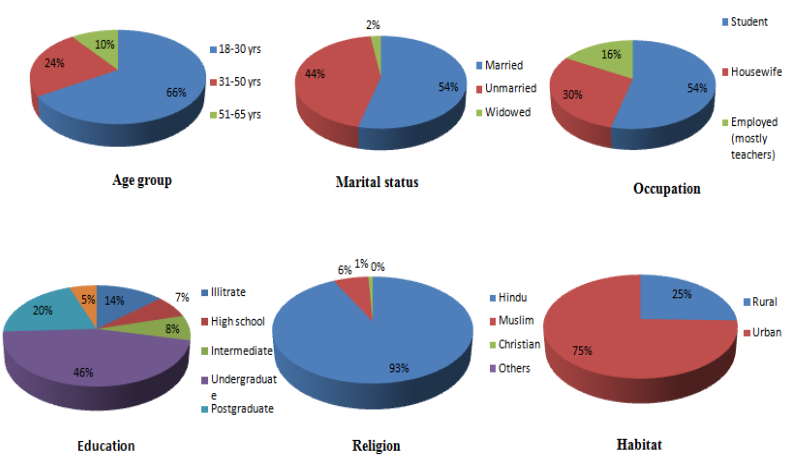

Figure 1. General information (age group, marital status, occupation, education level, religion and habitat) of participated women group above 30 yrs did not achieve parity (despite being married) as shown in Figure 2 and therefore they exposed themselves to longer duration of menstrual activity and it brings about higher risk of breast malignancy.

Along with this, a group of unmarried women, those are carrier oriented and belong to educated group as shown in Figure 3. Among 500, 220 women (44\%); their age group from 18 to $30+y$ rs did not achieve parity and hence they exposed themselves of different hormonal activity. This trend of Varanasi women has shown that, later age may promote the breast malignancy. The reasons for association between age at first parity and breast cancer risk are uncertain, but they probably relate either to changes in breast tissue susceptible to carcinogenesis

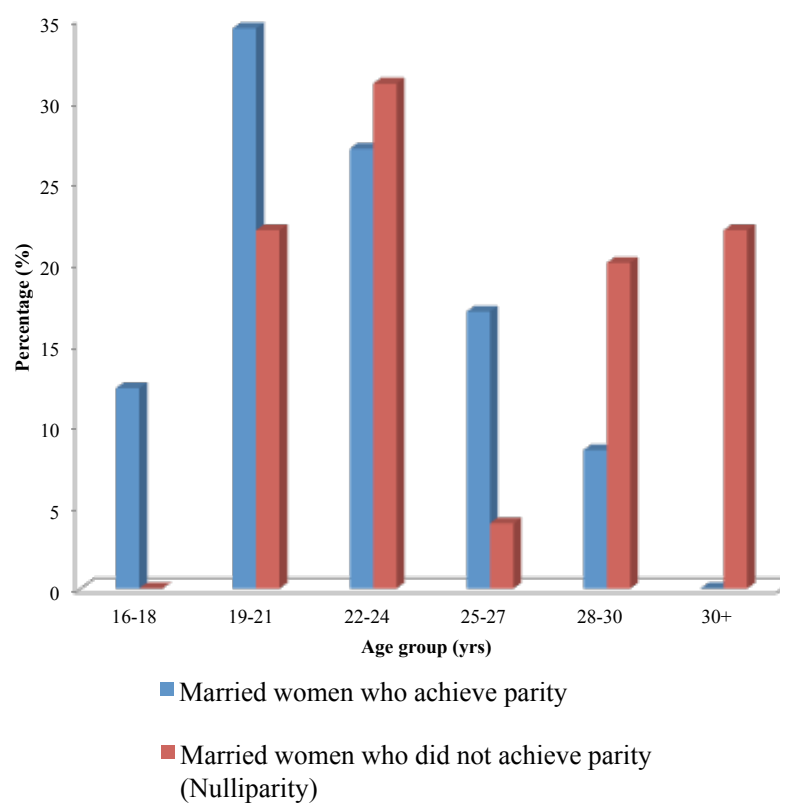

Figure 2. Percentage of participated married women with and without parity with their age group (yrs)

Table 3. Awareness about risk factors of breast cancer

\begin{tabular}{|c|c|c|c|c|}
\hline \multirow[t]{2}{*}{ Groups } & \multirow[t]{2}{*}{ Risk factor } & \multicolumn{2}{|c|}{$\mathrm{N}=500$} & \multirow[b]{2}{*}{ Can’t say $(\%)$} \\
\hline & & Yes $(\%)$ & No $(\%)$ & \\
\hline Group I & Age above 40 yrs & $231(46.2)$ & $124(24.8)$ & $145(29)$ \\
\hline \multirow[t]{6}{*}{ Age, marriage \& heredity factors } & Menarche below12 yrs & $89(17.8)$ & $253(50.6)$ & $158(31.6)$ \\
\hline & Menopause after 55 yrs & $131(26.2)$ & $202(40.4)$ & $167(33.4)$ \\
\hline & Late marriage & $169(33.8)$ & $178(35.6)$ & $153(30.6)$ \\
\hline & Nulliparity & $162(32.4)$ & $179(35.8)$ & $159(31.8)$ \\
\hline & Hormone therapy & $174(34.8)$ & $166(33.2)$ & $160(32)$ \\
\hline & Heredity & 271(54.2) & $121(24.2)$ & $108(21.6)$ \\
\hline Group II & Alcohol & $323(64.6)$ & $67(13.4)$ & $110(22)$ \\
\hline \multirow[t]{4}{*}{ Physical \& chemical factors } & Smoking & $320(64)$ & $71(14.2)$ & $109(21.8)$ \\
\hline & Pesticides/chemicals & $199(39.8)$ & $147(29.4)$ & $154(30.8)$ \\
\hline & Cosmetics & $128(25.6)$ & $208(41.6)$ & $164(32.8)$ \\
\hline & Radiation exposure & 245 (49) & $100(20)$ & $155(31)$ \\
\hline Group III & Sedentary life style & $200(40)$ & $136(27.2)$ & $144(28.8)$ \\
\hline \multirow[t]{6}{*}{ Life style factors } & Obesity & $238(47.6)$ & $137(27.4)$ & $135(27)$ \\
\hline & Stressful life & $219(43.8)$ & $136(27.2)$ & 145 (29) \\
\hline & Injury/accident in breast & $197(39.4)$ & $135(27)$ & $168(33.6)$ \\
\hline & Lack of physical exercise & $219(43.8)$ & $137(27.4)$ & $144(28.8)$ \\
\hline & Packed food & $136(27.2)$ & $193(38.6)$ & $171(34.2)$ \\
\hline & Red meat & $115(23)$ & $189(37.8)$ & $196(39.2)$ \\
\hline
\end{tabular}


Breast Cancer Associated Risk Factors and Screening Practices among Women in the Holy City Varanasi, Uttar Pradesh, India agent or to long-lasting changes in the hormonal milieu. A study has shown that on the basis of experiments in rats, the full cellular differentiation of mammary glands during a full term pregnancy protects against the subsequent development of breast cancer (Russo et al., 1982).

Knowledge and awareness of cancer, breast cancer and screening practices: $82 \%$ of participated women were aware about both cancers including breast cancer and $12 \%$ aware about only cancer not breast cancer but $6 \%$ responded that they do not know about cancer and breast cancer both, as shown in Figure 4.

In this study, it was found that, $16.6 \%$ women were aware about screening practices i.e., mammography as shown in Figure 4, whereas, it was significantly higher (89\%) among nursing students of Himachal Pradesh (Fotedar et al., 2013) and followed by $67.1 \%$ among teachers of Delhi (Khokhar, 2009). In Turkish women (Secginli and Nahcivan, 2006) and Nigerian women

(Olowokere et al., 2012) it was found $25 \%$ and $21.6 \%$, respectively.

The awareness and performance of BSE was $16 \%$ and $15.6 \%$, respectively in Varanasi, which was very low as compared to $97 \%$ and $54 \%$ in nursing students of Himachal Pradesh (Fotedar et al., 2013), 42\% and 15\% in Mumbai women (Ahuja and Chakrabarti, 2009), 36\% and $13.3 \%$ in Delhi teachers (Khokhar, 2009), 37.5\% and $17 \%$ in Turkish (Secginli and Nahcivan) and $52.8 \%$ and $51.6 \%$ in Nigerian women, respectively (Olowokere et al., 2012). Since, Varanasi is a holy city, where customs, traditions and social believes are much more and their education level is also not well regarding the BSE and hence, most of the women feeling shy, that's why the BSE performance in Varanasi city is very low.

Only $15.6 \%$ of women were performed BSE once in a year because one of their family member was exposed to cancer and advised by doctor to do so. The main reason for non-performance of BSE was that they did not know how

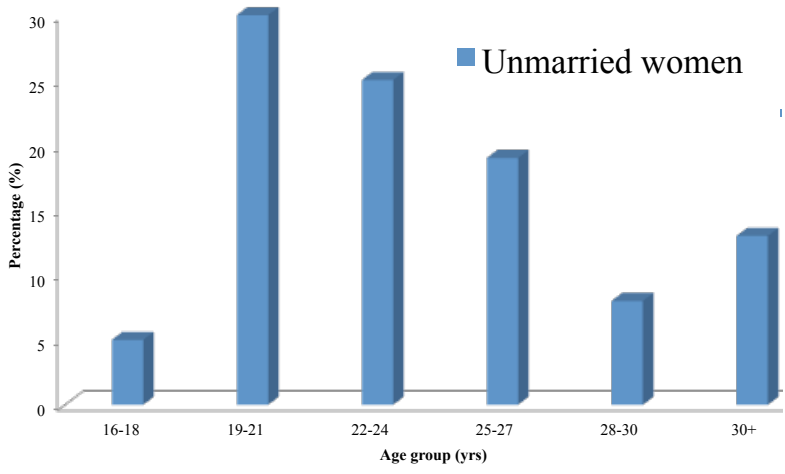

Figure 3. Percentage of participated unmarried women with their Age group

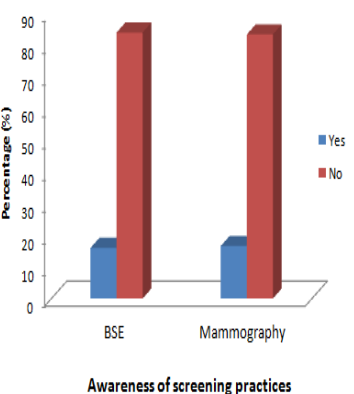

Figure 4. Knowledge about Cancer, Breast Cancer and Awareness of Screening Practices (BSE and Mammography)

Table 4. Factors that Helpful in the Recovery of Patients from Breast Cancer

\begin{tabular}{|c|c|c|c|c|c|c|c|}
\hline \multirow{3}{*}{$\begin{array}{l}\text { Group } \\
\text { Spirituality }\end{array}$} & \multirow{3}{*}{$\begin{array}{l}\text { Recovery factors } \\
\text { Spirituality }\end{array}$} & \multicolumn{6}{|c|}{$\mathrm{N}=500$} \\
\hline & & \multicolumn{2}{|c|}{ Yes $(\%)$} & \multicolumn{2}{|c|}{ No $(\%)$} & \multicolumn{2}{|c|}{ Can’t say (\%) } \\
\hline & & $327(65.4)$ & $332(66.4)$ & 99 (19.8) & 103 (20.6) & $74(14.8)$ & $65(13)$ \\
\hline & Prayer & $336(67.2)$ & & $106(21.2)$ & & $58(11.6)$ & \\
\hline Doctor's support & Doctor's support & $475(95)$ & & $8(1.6)$ & & $17(3.4)$ & \\
\hline \multirow[t]{2}{*}{ Family support } & Family & $472(94.4)$ & $460(92)$ & $13(2.6)$ & $16(3)$ & $15(3)$ & $24(5)$ \\
\hline & Spouse & $448(89.6)$ & & $20(4)$ & & $32(6.4)$ & \\
\hline \multirow[t]{2}{*}{ Life style } & Physical exercise & $405(81)$ & $399(79.8)$ & $60(12)$ & $63(12.6)$ & $35(7)$ & $38(7.6)$ \\
\hline & Modern life & $393(78.6)$ & & $66(13.2)$ & & $41(8.2)$ & \\
\hline
\end{tabular}

Table 5. Association between BSE (Peparate Responses) with verious level of Education

\begin{tabular}{|c|c|c|c|c|c|c|c|c|}
\hline \multicolumn{3}{|c|}{ Crosstab } & \multicolumn{5}{|c|}{ BSE } & \multirow[t]{2}{*}{ Total } \\
\hline & & & 0 & 1 & 2 & 3 & 4 & \\
\hline \multirow[t]{8}{*}{ Groups } & Illiterate & Count & 69 & 0 & 0 & 0 & 0 & 69 \\
\hline & & Expected count & 58.2 & 2.5 & 1.7 & 3.9 & 2.8 & 69 \\
\hline & High school \& Intermediate & Count & 65 & 5 & 3 & 3 & 1 & 77 \\
\hline & & Expected count & 65 & 2.8 & 1.8 & 4.3 & 3.1 & 77 \\
\hline & UG \& PG & Count & 277 & 12 & 6 & 14 & 19 & 328 \\
\hline & & Expected count & 276.8 & 11.8 & 7.9 & 18.4 & 13.1 & 328 \\
\hline & $\mathrm{PhD}$ & Count & 11 & 1 & 3 & 11 & 0 & 26 \\
\hline & & Expected count & 21.9 & 0.9 & 0.6 & 1.5 & 1 & 26 \\
\hline \multirow[t]{2}{*}{ Total } & & Count & 422 & 18 & 12 & 28 & 20 & 500 \\
\hline & & Expected count & 422 & 18 & 12 & 28 & 20 & 500 \\
\hline
\end{tabular}


Table 6. Association between BSE Performances (combined responses) with various level of esucation

\begin{tabular}{|c|c|c|c|c|c|}
\hline \multicolumn{3}{|c|}{ Crosstab } & \multicolumn{2}{|c|}{ BSE } & \multirow[t]{2}{*}{ Total } \\
\hline & & & $0.00+1.00$ cells & $2.00+3.00+4.00$ cells & \\
\hline \multirow[t]{8}{*}{ Groups } & Illiterate & Count & 69 & 0 & 69 \\
\hline & & Expected count & 60.72 & 8.28 & \\
\hline & High school \& Intermediate & Count & 70 & 7 & 77 \\
\hline & & Expected count & 77.88 & 9.24 & \\
\hline & UG \& PG & Count & 289 & 39 & 328 \\
\hline & & Expected count & 288.64 & 39.36 & \\
\hline & $\mathrm{PhD}$ & Count & 12 & 14 & 26 \\
\hline & & Expected count & 22.88 & 3.12 & \\
\hline \multicolumn{3}{|l|}{ Total } & 440 & 60 & 500 \\
\hline
\end{tabular}

Table 7. Descriptive of Mean and Standard Deviation of Habit with Different Education Groups

\begin{tabular}{lrcc}
\hline Groups & $\mathrm{N}$ & Mean & $\begin{array}{c}\text { Std. } \\
\text { Deviation }\end{array}$ \\
\hline Illiterate & 69 & 24.75 & 1.7 \\
High school \& Intermediate & 77 & 24.81 & 1.86 \\
UG \& PG & 328 & 25.68 & 1.72 \\
PhD & 26 & 25.76 & 1.86 \\
\hline Total & 500 & 25.42 & 1.79 \\
\hline
\end{tabular}

Table 8. Analysis of Variance of the Mean of Habit with Education Groups

\begin{tabular}{lrrrrr}
\hline Groups & $\begin{array}{r}\text { Sum of } \\
\text { squares }\end{array}$ & df & $\begin{array}{c}\text { Mean } \\
\text { square }\end{array}$ & F & Sig. \\
\hline Between groups & 84.871 & 3 & 28.29 & 9.198 & 0 \\
Within groups & 1525.537 & 496 & 3.076 & & \\
\hline Total & 1610.408 & 499 & & & \\
\hline
\end{tabular}

Table 9. ?Descriptive of mean and Standard Deviation of BSE performance with different

\begin{tabular}{lrlc}
\hline Groups & $\mathrm{N}$ & Mean & $\begin{array}{c}\text { Std. } \\
\text { Deviation }\end{array}$ \\
\hline Illiterate & 69 & 0 & 0 \\
High school \& Intermediate & 77 & 0.31 & 0.83 \\
UG \& PG & 328 & 0.43 & 1.11 \\
PhD & 26 & 1.53 & 1.42 \\
\hline Total & 500 & 0.41 & 1.05 \\
\hline
\end{tabular}

to perform the BSE. It is important to obviate their fears by demonstrating the correct method of BSE performance. There is a need of teaching program to promote BSE practice with the involvement of health care workers. In a study, the Health Belief Model was applied for practice of BSE and to promote it to overcome the practical barriers of BSE practice (Fung et al., 1998).

Awareness about the risk factor of breast cancer: The risk factors of breast cancer were mainly categorized in three groups as (i) age, marriage \& heredity, (ii) Physical \& chemical, (iii) life style factor. It was found that the awareness about these factors varies as age, marriage $\&$ heredity related risk factors was from 17.8 to $54.2 \%$, physical $\&$ chemical related risk factors responded by was

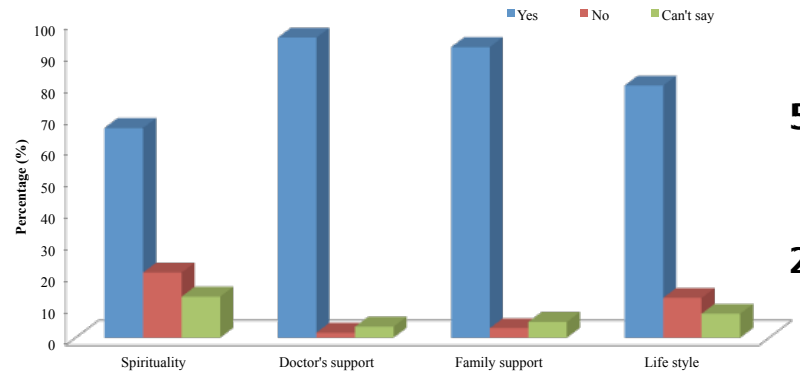

Figure 5. Responses of Women on Various Recovery Factors of Breast Cancer

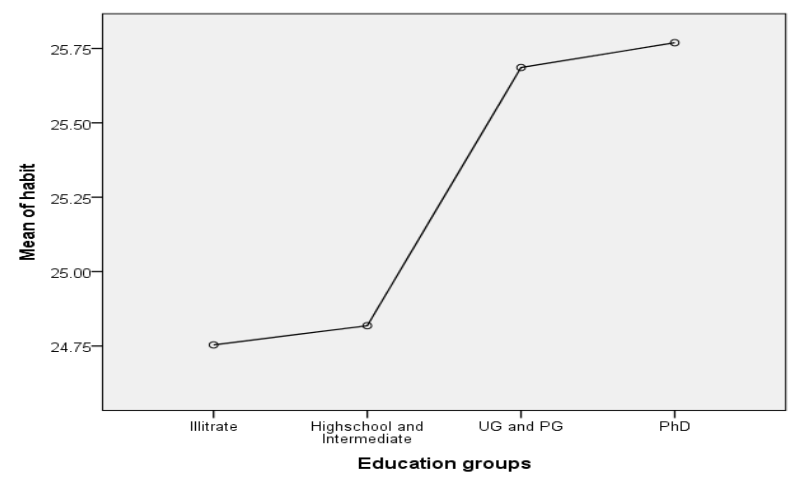

Figure 6. Graphical Comparison between the Mean of Habit with Different Education Groups

25.6 to $64.6 \%$ and life style related risk factors was 23 to $47.6 \%$. The well known positive risk factors of breast cancer were alcohol (64.6\%), smoking (64\%), heredity $(54.2 \%)$, radiation exposures $(49 \%)$, obesity $(47.6 \%)$ and the least awareness risk factors were menarche (17.8\%), use of red meat $(23 \%)$, cosmetics $(25.6 \%)$, menopause (26.2\%) and packed foods (27.2\%).

Age, marriege and heredity releated risk factors: The least awareness factors were early meanarche $(17.8 \%)$ followed by late menopause (26.2\%), nulliparity (32.4\%), late marriege (33.8\%) and hormone therapy (34.8\%). Most well known risk factors were heredity $(54.2 \%)$ and age above forties (46.2\%). Can't say response on these above risk factors were varies from $21.6 \%$ to $33.4 \%$ as shown in Table 3 (Group I: Age, marriage \& heredity factors). Similar results were reported previuosly as awareness on heredity factor in Delhi (Khokhar, 2009), Mumbai (Ahuja and Chakrabarti, 2009) and arab country Kuwait city (Alharbi et al., 2012) were 58\%, $42.5 \%$ and $54.2 \%$, 
Breast Cancer Associated Risk Factors and Screening Practices among Women in the Holy City Varanasi, Uttar Pradesh, India

Table 10.Aanlysis of Variance of the Mean Performance of BSE with Different Education

\begin{tabular}{lrrrrr}
\hline Table12 & $\begin{array}{r}\text { Sum of } \\
\text { squares }\end{array}$ & Df & $\begin{array}{r}\text { Mean } \\
\text { square }\end{array}$ & F value & Sig. \\
\hline Between groups & 45.623 & 3 & 15.208 & 14.863 & 0 \\
Within groups & 507.505 & 496 & 1.023 & & \\
\hline Total & 553.128 & 499 & & & \\
\hline
\end{tabular}

Table 11. Descriptive of Mean and Standard Deviation of Risk Factors

\begin{tabular}{lrcc}
\hline Groups & N & Mean & $\begin{array}{c}\text { Std. } \\
\text { Deviation }\end{array}$ \\
\hline Illiterate & 69 & 20.62 & 7.14 \\
High school \& Intermediate & 77 & 20.88 & 7.48 \\
UG \& PG & 328 & 21.33 & 8.14 \\
PhD & 26 & 25.73 & 7.92 \\
\hline Total & 500 & 21.39 & 7.95 \\
\hline
\end{tabular}

Table 12. Analysis of Variance of the Mean of Various Risk Factors of Breast Cancer with Different Education Groups

\begin{tabular}{|c|c|c|c|c|c|}
\hline Groups & $\begin{array}{l}\text { Sum of } \\
\text { squares }\end{array}$ & df & $\begin{array}{l}\text { Mean } \\
\text { square }\end{array}$ & F value & Sig. \\
\hline Between groups & 551.096 & 3 & 183.699 & 2.938 & 0.033 \\
\hline Within groups & 31010.702 & 496 & 62.522 & & \\
\hline Total & 31561.798 & 499 & & & \\
\hline
\end{tabular}

respectively. Further, responses of awareness on early menarche and age above forties were found in teachers of Delhi (Khokhar, 2009) and women of Kuwait city (Alharbi et al., 2012) $7.7 \%$ and $35.4 \%$ respectively. This study has shown that less number of women were aware about the association of these risk factors could cause the breast cancer. However, among all the studies, it was found that heredity factor is most identified risk factor.

Physical and chemical risk factors: Use of alcohol $(64.6 \%)$ and smoking (64\%) were most known risk factors followed by exposoure to radiation $(49 \%)$. The least known risk factors were use of pesticides (39.8\%) and cosmetics (25.6\%). However, a small fraction of women ( $22 \%$ to $33 \%$ ) were not aware about physical and chemical factors as causitive factor for breast cancer as shown Table 3 (Group II - Physical \& chemical factors). Furthermore, similar results were observed from the study in Mumbai, well known risk factors were alcohol (85\%) and smoking $(74 \%)$. Radiation exposure as risk factor was reported by $36 \%$ of women (Ahuja and Chakrabarti, 2009).

Life style releated risk factors: The most common awareness risk factors were as obesity (47.6\%), stressful life $(43.8 \%)$ and lack of physical exercise $(43.8 \%)$ as shown in Table 3 (Group III: Life style factors). Least known risk factors were as use of red meat $(23 \%)$, packed food $(27.2 \%)$. Injury or accident in breast as a causitive factor was responded by $39.4 \%$ women. In a study, obesity was not consider as a risk factor however, modern life style was considered as a risk factor of breast cancer by $15 \%$ of women (Ahuja and Chakrabarti, 2009).

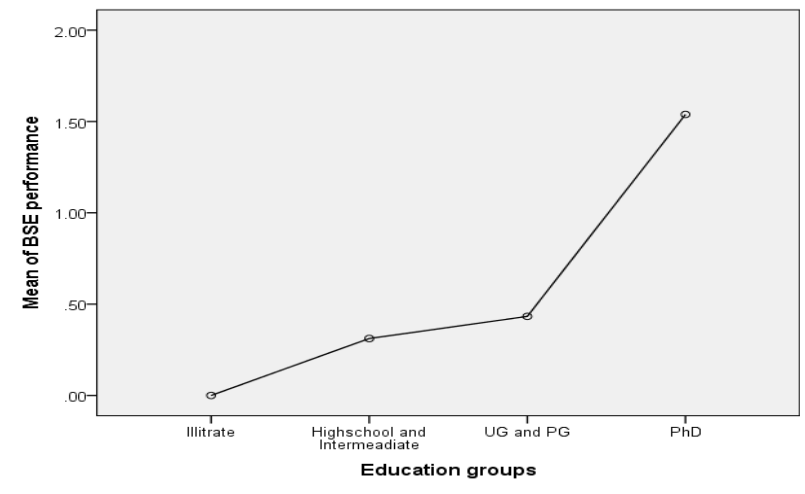

Figure 7. Graphical Comparison between Mean of BSE Performance with Different Education Groups

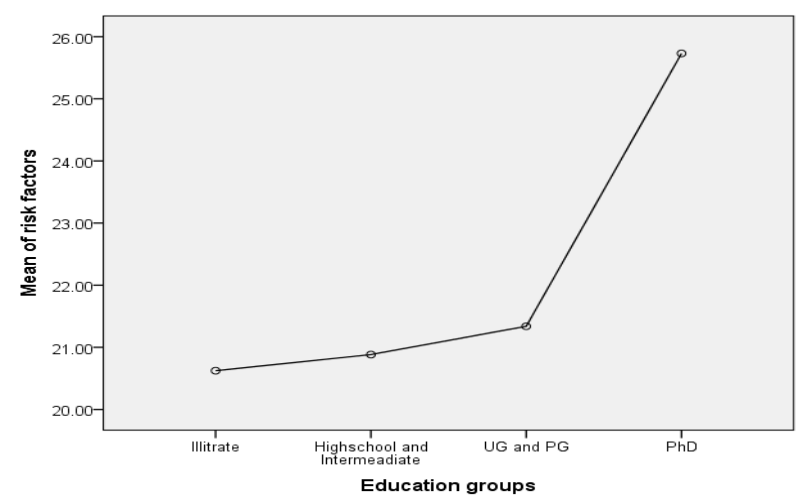

Figure 8. Graphical Comparison between the Mean of risk Factors of breast Cancer with Different Education Groups

Recovery factors of breast cancer: This was assessed by asking women, which factors they think would be responsible for helping in cure of breast cancer. As shown in Table 4 and Figure 5, doctor (95\%) and family support (92\%) were given high value for recovery of patient suffering from breast cancer, these factors were very significant. Since, Varanasi is holy city; therefore $66.4 \%$ of participants were responded that spirituality and prayer act as supportive factor for breast cancer. And change in active life style $(79.8 \%)$ may help as protective factor. Hence, social spiritual and scientific approaches (as it includes doctors) are the cope up factor by which patient get confidence.

\section{Statistical analysis}

Varanasi city is known as temple of learning city and on the basis of (statistical evidence) public health awareness, we have assumed that association of various factors like performance of BSE with various education group as well as significant level and mean of habit, BSE performance and knowledge of risk factors with the various education groups.

Association between BSE performances with various level of education: In this study, the chi-square test of independence was used to evaluate groups' differences. If the probability of test statistics is less than or equal to the probability of the alpha error rate and hence, null hypothesis was rejected. It may conclude that there is a relationship between the variables.

In above Table 5, many cells have less than 5 
frequencies. Therefore, the pulling method was used to obtain the cell frequency in each cell 5 or greater than 5 , thus the resulting Table 6 given below.

Degrees of freedom (d.f.) $=(\mathrm{c}-1)(\mathrm{r}-1)$, where $\mathrm{c}$ is column and $r$ is row Hence, degrees of freedom $=3$

$$
\begin{aligned}
& \chi_{\text {cal }}^{2}=\sum_{\mathrm{i}=1}^{\mathrm{n}} \frac{(\text { obsereved-expected })^{2}}{\text { expected }}=9.54 \\
& \chi_{\text {tab }(3,0.05)}^{2}=7.82\left(\because \chi_{\text {cal }}^{2}>\chi_{\text {tab }}^{2}\right) \\
& \text { i.e. } 9.54>7.82 \text { at } \alpha=0.05
\end{aligned}
$$

The null hypothesis that differences in "accuracy of the description of increase in education level towards their performance of BSE" are independent, so it is rejected at $5 \%(\alpha=0.05)$ level of significance and it is supported by this analysis. Thus, it may conclude that "accuracy of the description of increase in education level towards their performance of BSE" is associated.

Education with habit: Literacy too dictated on their habits, a definite trend was noticed showing clearly, that those belonging to higher education have subsequently scored higher as follows. (Applying the ANOVA the difference was found to be significant at $\mathrm{p}<0.002$ ).

Table 7 , has shown that the mean of habit with education is higher in $\mathrm{PhD}$ (25.76), followed by UG \& PG (25.68), high school \& intermediate (24.81) and least in illiterate (24.75). Table 8, shows that Fcal $(=9.198)>$ $\mathrm{F}_{[3,496), 0.05]}(=2.62)$. Thus, the result is significant and it may conclude that research hypothesis that the mean "Habits" for groups defined by the variable "Different Education Level" is not the same for all groups is supported by this analysis. However as shown in graphical representation (Figure 6), the way of living and their mean of habit also get increases as education level increase.

Education with BSE performance: Screening practice (BSE) was analysed and a definite trend was noticed showing clearly, that those groups belonging to higher education have better perform it. (Applying the ANOVA the difference was found to be significant at $\mathrm{p}<0.000$ ).

From Table 9, it is clear that the mean of performance of BSE with education is higher in $\mathrm{PhD}$ (1.53) which shows that their awareness and performance of BSE is more in compare to other groups, followed by UG \& PG (0.43), high school \& intermediate $(0.31)$ and illiterate (0.00).

Table 10, shows that Fcal $(=14.863)>F_{[3,496), 0.05]}$ (=2.62). Thus, the result is significant and it may conclude that research hypothesis that the mean "BSE performance" for groups defined by the variable "Different Education Level" is not the same for all groups is supported by this analysis. However, as shown in graphical representation (Figure 7), that the education level increases the performance of BSE also increase.

Education with risk factors awareness: Knowledge and awareness on causative factors of breast cancer was analysed with education and a definite trend was noticed and their mean showing clearly, those group belonging to higher education they are more aware about the risk factors of breast cancer. (Applying the ANOVA the difference was found to be significant at $\mathrm{p}<0.033)$.

It appears in the Table 11, that the awareness mean of causative factors of breast cancer with education is higher in $\mathrm{PhD}$ (25.73) followed by UG \& PG (21.33), high school $\&$ intermediate (20.88) and least in illiterate (20.62). Table 12 shows that Fcal $(=2.938)>\mathrm{F}_{[3,496), 0.05]}(=2.62)$. Thus, the result is significant and it may conclude that research hypothesis that the mean "Awareness of Risk Factors" for groups defined by the variable "Different Education Level" is not the same for all groups is supported by this analysis. However, as shown in graphical representation (Figure 8), as the education level increases their awareness about the risk factors of breast cancer is also increase simultaneously.

\section{Discussion}

The present study reveals that the awareness and knowledge on breast cancer is moderate and awareness on risk factors of breast cancer is low as compare to other cities. Although, it is holy city but the responses for doctor's support and family support are most well known from the recovery of breast cancer. Present study data has drawn our attention that nowadays women are carrier oriented and they delayed to achieve their parity. The longer exposure of menstrual activity causes the moderate advancement in the risks of breast cancer. But the protective factor is to attain the party below $27 \mathrm{yrs}$ and practice of BSE. It is considered as important tool in the early detection of breast cancer but many barriers are myths, cultural beliefs (Shrisvastava et al., 2013), not know the correct method (Ahuja and Chakrabarti, 2009), lack of knowledge (Alwan et al., 2012), lack of interest and not able to understand the importance of BSE (Gupta et al., 2009), social constrains (Rasu et al., 2011). These factors are interfering with practice of BSE. All women are need to encourage and being responsible for their own health. According to the Sheryl Crow (an American singer diagnosed with breast cancer), "The only person who can save you is you: That was going to be the thing that informed the rest of my life". Therefore, the need of BSE practise should be encourage by involvement of electronic media, television and radio. Various government and non-government organisation with integration of doctors, hospitals, clinics and nowadays it is need for regular update of courses for health worker focusing on breast cancer education and screening practises. So, that greatest challenge of last stage diagnosis of breast cancer will be stop and it will rise in number of early diagnosis of breast cancer.

\section{Acknowledgements}

Authors are thankful to DST New Delhi for financial support and Head, Department of Chemistry, BHU, Varanasi for providing all the necessary facilities. Our sincere thank to all participants for active participation and Principal, Ashirward Nursing College and Heritage Nursing College for encouraging participants. Authors are also thankful to Ms. Anukampa Pandey and Ms. Haleema Sabia, Department of Bioinformatics, MMV, BHU to help in data collection and Dr. M. K. Choudhary, Department 
Breast Cancer Associated Risk Factors and Screening Practices among Women in the Holy City Varanasi, Uttar Pradesh, India of Statistics, BHU to help in statistical analysis.

\section{References}

Ahuja S, Chakrabarti N (2009). To determine the level of knowledge regarding breast cancer and to increase awareness about breast cancer screening practises among a group of women in a tertiary care hospital in Mumbai, India. Int $J$ Public Health, 1, 1.

Alharbi NA, Alshammari MS, Almutairi BM, et al (2012). Knowledge, awareness, and practices concerning breast cancer among Kuwaiti female school teachers. Alexandria $J$ Med, 48, 75-82.

Alwan, NAS, Al-Attar WM, Eliessa RA, et al (2012). Knowledge, attitude and practise regarding breast cancer and breast self examination among a sample of the educated population in Iraq. East Mediterr Health J, 18, 337- 45.

Austoker J (2003). Breast Self Examination (Does not prevent deaths due to breast cancer, but breast awareness is still important). $B M J$, 326, 1-2.

Ferlay J, Shin HR, Bray F, et al (2010). Estimates of worldwide burden of cancer in 2008: GLOBOCON 2008. Int J Cancer, 127, 2893-917.

Fotedar V, Seam RK, Gupta MK, et al (2013). Knowledge of risk factors \& early detection methods and practices towards breast cancer among nurses in Indira Gandhi Medical, Shimla, Himachal Pradesh, India. Asian Pac J Cancer Prev, 14, 117-20.

Fung SY (1998). Factor associated with breast self-examination behaviour among Chinese women in Hong Kong. Patient Educ Couns, 33, 233-43.

Gajalakshmi V, Mathew A, Brennan P, et al (2009). Breast feeding and breast cancer risk in India: A multicenter casecontrol study. Int J Cancer, 125, 662-5.

Ganjewala D (2009). Prevalence of cancers in some parts of Madhya Pradesh and Uttar Pradesh in India. Academic $J$ Cancer Res, 2, 12-8.

Greenlee RT, Murray T, Bolden S, et al (2000). Cancer Statistics, 2000. Ca Cancer J Clin, 50, 7-33.

Gupta S, Rao YN, Agarwal SP (2002). Emerging strategies for cancer control in women of India (50 years of Cancer Control in India), Editor: Agarwal SP, Directorate General of Health services, Ministry of Health and Family Welfare, Govt. of India. 184-95.

Gupta SK, Pal DK, Garag R, et al (2009). Impact of a health education intervention program regarding breast self examination by women in a semi - urban area of Madhya Pradesh, India. Asian Pac J Cancer Prev, 10, 1113-7.

Harrison PA, Srinivasan K, Binu VS, et al (2010). Risk factors for breast cancer among women attending a tertiary care hospital in southern India. Int. J. Collab. Res. Internal Med. Public Health, 2, 109-16.

Jennifer LK, Marilie DG, Esther MJ (1993). Reproductive factor and breast cancer. Epidemiol Rev, 15, 36-47.

Khokhar A (2009). Level of awareness regarding breast cancer and its screening amongst Indian teachers. Asian Pac J Cancer Prev, 10, 247-50.

Khokhar A (2012). Breast Cancer in India: Where do we stand and where do we go? Asian Pac J Cancer Prev, 13, 4861-6.

Leong SPL, Shen ZZ, Liu TJ, et al (2010). Is breast cancer the same disease in Asian and Western countries? World J Surg, 34, 2308-24.

Meshram II, Hiwarkar PA, Kulkarni PN (2009). Reproductive risk factors for breast cancer: A case control study. Online $J$ Hlth Allied Scs, 8, 1-4.

Olowokere AE, Onibokun AC, Oluwatosin AO (2012). Breast cancer knowledge and screening practices among women 